Expert Radiology Application Softwares Enhance Radiology Diagnosis Contributions And Challenges By A Historical Review of Informetric Analysis From 1991To 2021

\title{
Chia-Cheng Chao
}

Department of Information Science, National Taipei University of Education, Taipei, Taiwan, email: vc88888@gmail.com

\section{Ming-Hung Hsu}

Department of Electrical Engineering, National Penghu University of Science and Technology, Magong, Penghu, Taiwan, e-mail:hsu.mh@msa.hinet.net

\begin{abstract}
In all areas of medicine, especially in radiology, computers are increasing year by year. Filmless radiology, speech recognition software, electronic application forms, and teleradiology are recent developments that have greatly improved radiologists' performance. This research explores radiology software trends, predictions, and the challenges posed by informatics and historical trend analysis. The rationale behind this research is that information technology (IT) is overgrowing almost every day. We must continuously seek new ways to apply IT to make more use of resources. Consequently, IT becomes increasingly crucial to radiology organizations' innovative thinking, workflow, and business models. This study aimed to analyze all radiology software publications in the Science Citation Index (SCI). From 1991 to July 2021, SCI was used to search for publications systematically. We have also widely used this historical method in radiology software research. The findings and discussions are base on an assessment of trends, predictions, contributions, and challenges in radiology software, and we are exploring radiology software with six evolutionary stages. The gift of this research is that radiology managers realize that the use of new information technologies is closely related to survival in a competitive environment. Radiology companies can review these new technologies to develop more innovative business models and services to improve operational deficiencies.
\end{abstract}

Keywords: radiology information systems, radiology education system, radiology operation software, information technology, computer-aided diagnosis system 


\section{I.Introduction}

The use of computers is increasing in all fields of medicine, especially in radiology. The latest developments in membraneless radiology, speech recognition software, electronic application forms, and teleradiology have greatly improved the performance of radiologists [1]. This study aimed to explore trends, predictions, information challenges, and historical trend analysis of radiology software. Advances in emerging radiology information technology have made the global radiology business environment a vibrant market. The hospital will continue to face new radiation technologies and competition as well as gradually increase patient expectations. To compete in the new radiology, IT environment, commercial new IT technology alliances, radiology departments, radiology departments, doctors must coordinate inspection activities globally. This situation requires sharing knowledge, new technology drivers and patient inspection mechanisms, and links to radiology innovation design and information technology (IT) to implement these new business models. However, radiologists face fundamental changes in their pursuit of ambitious goals rather than incremental changes. Innovation is rapidly evolving, continually adopting new forms of technology and assessing its value in improving day-to-day operations [2]. Innovation is quickly changing, constantly embracing new technology forms and evaluating its importance in enhancing day-to-day operations [2]. We expect Computer graphics, visualization, and virtual environment applications in the medical field to improve health care and benefits that bring considerable opportunities to patients [3].

The rationale behind this research is that information technology (IT) is increasing more powerful operation almost every day. We must always strive to apply it to new ways of using more resources. Therefore, it is essential to create new ways of thinking about radiology, workflow, and business models. Radiology organizations can not only use intellectual capital and information technology to improve their business deficiencies, but radiology directors are also committed to addressing the ongoing business crisis. They invest in reconfiguring resources and knowledge, creating innovative structures and systems to overcome problems and seek more efficient operations.

There is no doubt that computer and communication hardware have reached a state of complexity and availability, in which any necessary information can be generated, stored, and distributed to healthcare personnel to support their patient care tasks [4]. The understanding and contribution of radiology information technology innovation adopting trends, application history review, and information analysis research methods apply to this study.

This study aims to analyze all radiology software publications in the Science Citation 
Index (SCI). From 1991 to July 2021, we used t the Science Citation Index (SCI) to retrieve publications. Research findings and discussion of changing trends, predictions, and challenges of radiology software, we are exploring radiology software with six evolutionary stages; before 1990, most radiology information systems were designed for patient examination purposes. From 1990 to 2009, radiology software was Intranet connected. From 2011 to 2021, mobile devices such as PDAs, laptops, and mobile phones became an essential part of our lives. Then the era of radiation mobile began to innovate, while new business models and long-distance services, patient care became more valuable and efficient. The development of radiology has already started.

Later, Radiation Medical Artificial Intelligence technology was developed to integrate machines and software to achieve better quality and high-performance services, while large-scale integrated development with patient radiation extensive data software services. Since then, the era of machine learning has begun to provide diagnostics for diseases such as radiology. Also, the radiology software informatics review evolved into a strategic style of operations, education, management, and radiology software. It enhances the radiology director's ability to become a blueprint or reference application for emerging radiology software, thereby providing patients with safe, efficient services, improved competitive advantage, and more modern radiology service capabilities. It evolved into a strategic style of operation, education, management, and radiology software. It enhances the radiology director's ability to become a blueprint or reference application for emerging radiology software, thereby providing patients with safe, efficient services, improved competitive advantage, and more modern radiology service capabilities. It evolved into a strategic style of operation, education, management, and radiology software. It enhances the radiology director's ability to become a blueprint or reference application for emerging radiology software, thereby providing patients with safe, efficient services, increased competitive advantage, and more modern radiology service capabilities. 


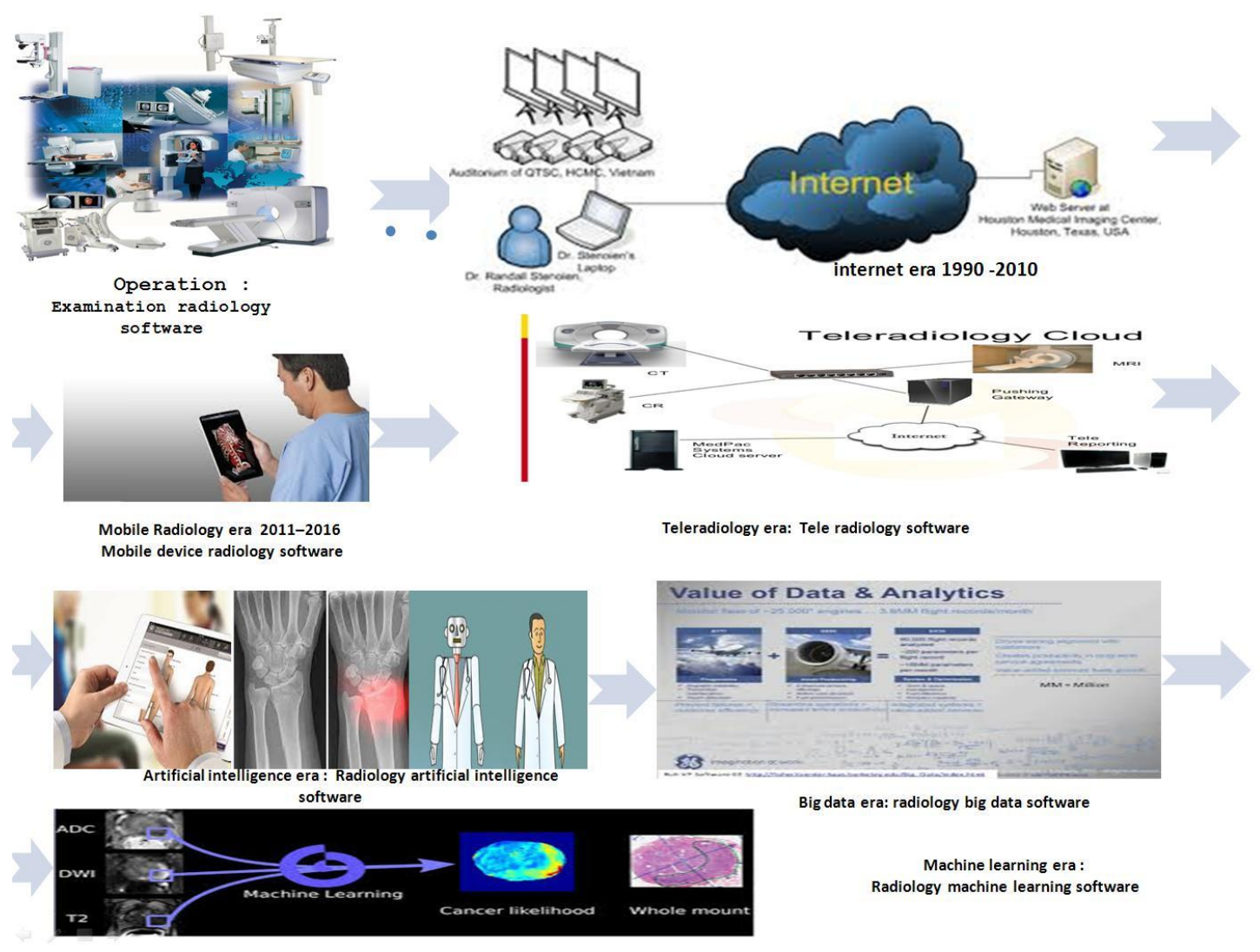

Figure 1 Radiology software evolution trend diagram

The main contribution of this research is to make radiology managers aware of the key to learning to use new information technologies to survive in a competitive environment [5]. The Radiology department director can use this innovative software in his department to improve operational efficiency and service quality. Radiology companies can look at these new technologies to develop further business models and services, strengthen business deficiencies in the past, and generate more business revenue from academic contribution, academic research on the exploration of innovation diffusion theory. It directly guides companies to improve existing machines, software, or operational errors and faces operational problems to improve innovative technologies, provide better services, and improve service quality and performance.

As a result, radiology has also begun to use information technology to solve more effective and accurate problems, such as using new and innovative systems for patient testing and diagnosis and competition for business, education, operations, and service needs. Therefore, radiology software resources and workflow, patient diagnostic safety management solutions, optimize asset utilization, reduce operating costs, and improve patient care in the medical industry; the world is based on various medical radiology applications developed. There are more radiation systems, and this hospital is using them. This article will explore the 
trends through the 1991 Informatics and Historical Review Trends and Radiology Software Technology. By 2021, we will clarify the trends in technology, analyze their contributions, and predict trends and challenges through radiology software.

\section{Literature review Diffusion of Innovation Theory}

The diffusion of Everett Rogers defines it as a process through which the social system members propagate innovation through individual channels over time. The definition of Rogers includes four elements of communication that exist in the innovation process: (1) Innovation - by individuals or other adopting units as new ideas, practices, or object perceptions. (2) Communication channel - the message from one person to another device; (3) Time, including (a) the innovative decision-making process; (b) the relative time of innovation of individuals or groups in (b);(4) Three-time factors of the social system - a group of people involved in solving problems together to achieve a common goal.

The Internet is an indispensable part of almost all radiologists' daily lives. Nevertheless, few people fully understand how it works or how to make the most of workplace technology. These analysis tables will explore the basics of computer networks and make the Internet a valuable resource. In addition, we will discuss the process of designing and implementing radiation management and education websites or intranet websites. Developing a website, what it contains, how to use it for ease of use, free provisioning, and two-way cost software to achieve this goal is also an essential point of view for applying this software [6]. Table 1, 2, 3, illustrate the operation type software of radiology for X-ray, CAD, CT, MRI, PACE, speech recognition, 3D, 4D, artificial intelligence, and electronic radiology reporting system.

Table 1 Operation type software of radiology

\begin{tabular}{|l|l|l|l|l|}
\hline No & $\begin{array}{l}\text { Style Software } \\
\text { Type } \\
\text { OPERATION }\end{array}$ & Method & Contribution & Author \\
\hline 1. & $\begin{array}{l}\text { X-ray } \\
\text { ViewDEX (X-ray } \\
\text { image digital } \\
\text { evaluation } \\
\text { viewer) }\end{array}$ & $\begin{array}{l}\text { ViewDEX is } \\
\text { compatible with } \\
\text { DICOM, and its } \\
\text { interface features } \\
\text { are versatile and } \\
\text { flexible. }\end{array}$ & $\begin{array}{l}\text { An efficient and easy to use } \\
\text { observer performance study } \\
\text { software }\end{array}$ & $\begin{array}{l}\text { Hakansson, } \\
\text { M; } \\
\text { Svensson, S; } \\
\text { Zachrisson, } \\
\text { S; Svalkvist, } \\
\text { A; Bath, M; } \\
\text { 2. }\end{array}$ \\
$\begin{array}{l}\text { CAD } \\
\text { computer-aided }\end{array}$ & $\begin{array}{l}\text { A method to use a } \\
\text { chest X-rays film }\end{array}$ & $\begin{array}{l}\text { This CAD system for chest } \\
\text { X-rays helps radiologists }\end{array}$ & $\begin{array}{l}\text { Kakeda, S; } \\
\text { Moriya, J; }\end{array}$ \\
\hline
\end{tabular}




\begin{tabular}{|c|c|c|c|c|}
\hline & $\begin{array}{l}\text { diagnosis (CAD) } \\
\text { system } \\
\text { EpiSight/XR }\end{array}$ & $\begin{array}{l}\text { for automatically } \\
\text { detecting nodules }\end{array}$ & $\begin{array}{l}\text { improve lung nodules } \\
\text { caused by lung cancer }\end{array}$ & $\begin{array}{l}\text { Sato, H; } \\
\text { Aoki, T; } \\
\text { Watanabe, } \\
\text { H; Nakata, } \\
\text { H; Oda, N; } \\
\text { Katsuragaw } \\
\text { a, S; } \\
\text { Yamamoto, } \\
\text { K; Doi, K } \\
\quad \text { [8]. }\end{array}$ \\
\hline 3. & CAD & $\begin{array}{l}\text { The CAD } \\
\text { environment is } \\
\text { subject to the } \\
\text { developmental } \\
\text { process of three } \\
\text { systems: multiple } \\
\text { sclerosis CAD, } \\
\text { lung nodule CAD, } \\
\text { and } \\
\text { pneumothorax } \\
\text { CAD. }\end{array}$ & $\begin{array}{l}\text { The operators can easily } \\
\text { handle CAD designers in } \\
\text { a user-friendly manner by } \\
\text { choosing various } \\
\text { workflow paths. }\end{array}$ & $\begin{array}{l}\text { Pietka, E; } \\
\text { Kawa, J; } \\
\text { Badura, P; } \\
\text { Spinczyk, D } \\
\text { [9]. }\end{array}$ \\
\hline 4. & $\begin{array}{l}\text { CAD } \\
\text { a computed } \\
\text { tomographic lung } \\
\text { nodule is a type } \\
\text { of } \\
\text { computer-aided } \\
\text { detection (CAD) } \\
\text { software }\end{array}$ & $\begin{array}{l}\text { As a second } \\
\text { reader for } \\
\text { radiology } \\
\text { residents. }\end{array}$ & $\begin{array}{l}\text { CAD software can aid in } \\
\text { refining the sensitivity of } \\
\text { residents to detect lung } \\
\text { nodules on computed } \\
\text { tomography, making them } \\
\text { comparable to } \\
\text { board-certified radiologists. }\end{array}$ & $\begin{array}{l}\text { Teague, SD; } \\
\text { Trilikis, G; } \\
\text { Dharaiya, E } \\
\text { [10]. }\end{array}$ \\
\hline
\end{tabular}

Table 2 Operation type software of radiology

\begin{tabular}{|l|l|l|l|l|}
\hline No & $\begin{array}{l}\text { Style Software } \\
\text { Type } \\
\text { OPERATION }\end{array}$ & Method & Contribution & Author \\
\hline 5. & $\begin{array}{l}\text { CT } \\
\text { angiography, } \\
\text { volume rendering }\end{array}$ & $\begin{array}{l}\text { With interactive } \\
\text { parameter } \\
\text { changes }\end{array}$ & $\begin{array}{l}\text { Post-processing } \\
\text { applications add to the } \\
\text { advantages of spiral CT }\end{array}$ & $\begin{array}{l}\text { KA; } \\
\text { Prokop, M }\end{array}$ \\
\hline
\end{tabular}




\begin{tabular}{|c|c|c|c|c|}
\hline & $\begin{array}{l}\text { techniques } \\
\text { (VRT) }\end{array}$ & & $\begin{array}{l}\text { 3D imaging of soft tissue } \\
\text { will also become feasible } \\
\text { through interactive } \\
\text { parameter changes }\end{array}$ & {$[11]$.} \\
\hline 6. & $\begin{array}{l}\text { CT } \\
\text { Micro-computed } \\
\text { tomography } \\
\text { (Micro-CT) }\end{array}$ & $\begin{array}{l}\text { The analysis tool } \\
\text { marks the pattern } \\
\text { damage on the } \\
\text { bone. Detailed } \\
\text { analysis of 3D } \\
\text { (3D) architecture } \\
\text { using } \\
\text { high-resolution } \\
\text { Micro-CT and } \\
\text { computer } \\
\text { software }\end{array}$ & $\begin{array}{l}\text { It is possible and allows for } \\
\text { the collecting of } \\
\text { microstructured 3D bone } \\
\text { information. Analysis of } \\
\text { bone damage indicates that } \\
\text { Micro-CT provides an } \\
\text { opportunity to correlate } \\
\text { bone damage with } \\
\text { instruments that cause } \\
\text { corrosion. }\end{array}$ & $\begin{array}{l}\text { Thali, MJ; } \\
\text { Taubenreuth } \\
\text { er, U; } \\
\text { Karolczak, } \\
\text { M; Braun, } \\
\text { M; } \\
\text { Brueschweil } \\
\text { er, W; } \\
\text { Kalender, } \\
\text { WA; } \\
\text { Dirnhofer, R } \\
\text {, } \\
\text { Forensic } \\
\text { [12]. }\end{array}$ \\
\hline 7. & $\begin{array}{l}\text { DICOM: } \\
\text { Digital image } \\
\text { communication } \\
\text { of medicine }\end{array}$ & $\begin{array}{l}\text { It downloads } \\
\text { image data from a } \\
\text { remote site: } \\
\text { requests to } \\
\text { retrieve data from } \\
\text { long-term storage; } \\
\text { view images and } \\
\text { perform certain } \\
\text { DICOM routing } \\
\text { operations. }\end{array}$ & $\begin{array}{l}\text { The existing infrastructure } \\
\text { of the Internet is beneficial } \\
\text { for developing a low-cost } \\
\text { system that can use for } \\
\text { teleradiology. }\end{array}$ & $\begin{array}{l}\text { Henri, CJ; } \\
\text { Rubin, RK; } \\
\text { Cox, RD; } \\
\text { Bret, PM } \\
\text { [13]. }\end{array}$ \\
\hline 8. & $\begin{array}{l}\text { Dicom } \\
\text { RadPix (R) } \\
\text { Video, we can } \\
\text { import } \\
\text { multi-frame } \\
\text { cine DICOM } \\
\text { (Digital } \\
\text { Imaging and } \\
\text { Communication } \\
\text { s in Medicine) }\end{array}$ & $\begin{array}{l}\text { Users can easily } \\
\text { crop and annotate } \\
\text { data. Easily create } \\
\text { annotated movie } \\
\text { ultrasound files. }\end{array}$ & $\begin{array}{l}\text { Successfully incorporated } \\
\text { radiology education }\end{array}$ & $\begin{array}{l}\text { Friedkin, } \\
\text { AM; } \\
\text { Weadock, } \\
\text { WJ, [14]. }\end{array}$ \\
\hline
\end{tabular}


Table 3 Operation type software of radiology

\begin{tabular}{|c|c|c|c|c|}
\hline No & $\begin{array}{l}\text { Style Software } \\
\text { Type } \\
\text { OPERATION }\end{array}$ & Method & Contribution & Author \\
\hline 9. & $\begin{array}{l}\text { MRI } \\
\text { Magnetic } \\
\text { Resonance } \\
\text { Imaging } \\
\text { Workbench } \\
\text { MRIW: } \\
\text { Parametric } \\
\text { analysis software }\end{array}$ & $\begin{array}{l}\text { Monitor changes } \\
\text { in disease status } \\
\text { and assesses } \\
\text { treatment } \\
\text { outcomes }\end{array}$ & $\begin{array}{l}\text { Contrast-enhanced analysis } \\
\text { during MR imaging is a } \\
\text { promising new approach to } \\
\text { data analysis in radiology } \\
\text { for such qualitative or } \\
\text { quantitative parameters. }\end{array}$ & $\begin{array}{l}\text { Parker, } \\
\text { GJM; } \\
\text { Suckling, J; } \\
\text { Tanner, SF; } \\
\text { Padhani, } \\
\text { AR; } \\
\text { Husband, } \\
\text { JE; Leach, } \\
\text { MO [15]. }\end{array}$ \\
\hline 10. & $\begin{array}{l}\text { MRI } \\
\text { Magnetic } \\
\text { resonance } \\
\text { imaging (MRI) }\end{array}$ & $\begin{array}{l}\text { It is an imaging } \\
\text { modality for } \\
\text { detecting disease } \\
\text { and pathology. } \\
\text { Excellent } \\
\text { soft-tissue } \\
\text { contrast in MRI } \\
\text { can better define } \\
\text { pathology. }\end{array}$ & $\begin{array}{l}\text { MRI has been increasingly } \\
\text { used to guide, monitor, and } \\
\text { control percutaneous } \\
\text { surgery and surgery. }\end{array}$ & $\begin{array}{l}\text { Blanco, RT; } \\
\text { Ojala, R; } \\
\text { Kariniemi, } \\
\text { J; Perala, J; } \\
\text { Niinimaki, } \\
\text { J; Tervonen, } \\
\text { O [16]. }\end{array}$ \\
\hline 11. & $\begin{array}{l}\text { PACS } \\
\text { Picture archiving } \\
\text { and } \\
\text { communication } \\
\text { systems (PACS) }\end{array}$ & $\begin{array}{l}\text { It converts } \\
\text { film-based } \\
\text { radiology into a } \\
\text { computer-based } \\
\text { digital } \\
\text { environment. }\end{array}$ & $\begin{array}{l}\text { It saves costs and improves } \\
\text { doctor communication. }\end{array}$ & $\begin{array}{l}\text { Arenson, } \\
\text { RL; } \\
\text { Chakraborty } \\
\text {, DP; } \\
\text { Seshadri, } \\
\text { SB; Kundel, } \\
\text { HL [17]. }\end{array}$ \\
\hline
\end{tabular}

Table 4 and Table 5 show the operation type software of radiology. Radiology and radiologists consider being an increasingly valuable resource in anatomy teaching. It is a state-of-the-art radiology workstation with industry-standard application software to provide the latest in fascinating pathology and physiology.

PACS diagnostic workstation. This environment includes all the tools used to create the teaching files, including text descriptions, annotations, and image processing [19]. 
Understanding informatics principles is crucial because they affect PACS and other supporting software and the model itself [20]. CT and the latest MRI, with software processing (interactive data display, contour detection and summation, imaginary 3D structure, and interactive visualization), provide further analysis improvements that are now available to make a single model [21]. The essential information is needed. Computer-aided detection (CAD) has attracted a wide range of research interests [22]. The following operating software section uses the latest voice-to-text IT technology to design these systems to improve operational efficiency. Speech recognition (SR) in a radiation environment is a way to reduce management costs by reducing or eliminating transcriptional services and reducing reporting time by reducing reporting time [23].

Table 4 Operation type software of radiology

\begin{tabular}{|c|c|c|c|c|}
\hline No & $\begin{array}{l}\text { Style Software } \\
\text { Type } \\
\text { OPERATION } \\
\text { Reporting } \\
\text { system } \\
\text { voice } \\
\text { recognition }\end{array}$ & Method & Contribution & Author \\
\hline 1 . & $\begin{array}{l}\text { Voice } \\
\text { recognition } \\
\text { systems used for } \\
\text { radiology } \\
\text { reporting. }\end{array}$ & $\begin{array}{l}\text { It uses a speech } \\
\text { recognition } \\
\text { system in the } \\
\text { transcription of } \\
\text { radiology reports. }\end{array}$ & $\begin{array}{l}\text { The radiologist can use the } \\
\text { normal speech mode for } \\
\text { dictation while reviewing } \\
\text { the film. Reduce the } \\
\text { hardware cost to a level } \\
\text { acceptable to radiology } \\
\text { using a standard personal } \\
\text { computer }\end{array}$ & $\begin{array}{l}\text { Schwartz, } \\
\text { LH; } \\
\text { Kijewski, P; } \\
\text { Hertogen, } \\
\text { H; Roossin, } \\
\text { PS; } \\
\text { Castellino, } \\
\text { RA [24]. }\end{array}$ \\
\hline 2 . & $\begin{array}{l}\text { To Making a } \\
\text { quantitative } \\
\text { computed } \\
\text { tomography } \\
\text { (QCT) reporting } \\
\text { system }\end{array}$ & $\begin{array}{l}\text { It illustrates the } \\
\text { practical use of } \\
\text { the QCT reporting } \\
\text { system in a } \\
\text { radiology reading } \\
\text { environment by } \\
\text { using optical } \\
\text { character } \\
\text { recognition } \\
\text { (OCR) and macro } \\
\text { programs. }\end{array}$ & $\begin{array}{l}\text { This method is easily } \\
\text { adaptable to other QCT } \\
\text { applications and PACS / } \\
\text { EMR. } \\
\text { (1) Save the QCT report as } \\
\text { a graphic file; (2) Identify } \\
\text { the characters in the image } \\
\text { as text; (3) Extract the } \\
\text { T-score from the text; (4) } \\
\text { Perform error correction; } \\
\text { (5) Reformat the value to }\end{array}$ & $\begin{array}{l}\text { Lee, YH; } \\
\text { Song, HT; } \\
\text { Suh, JS } \\
{[25] .}\end{array}$ \\
\hline
\end{tabular}




\begin{tabular}{|c|c|c|c|c|}
\hline & & $\begin{array}{l}\text { Designed for } \\
\text { OCR to report } \\
\text { QCT images } \\
\text { during } \\
\text { radiological } \\
\text { reading. }\end{array}$ & $\begin{array}{l}\text { The QCT radiology report } \\
\text { template, and (6) paste the } \\
\text { report into an electronic } \\
\text { medical record (EMR), or it } \\
\text { can be a picture archiving } \\
\text { and communication system } \\
(\mathrm{PACS}) \text {. }\end{array}$ & \\
\hline 3. & $\begin{array}{l}\text { computer } \\
\text { speech } \\
\text { recognition } \\
\text { system (SRS) for } \\
\text { clinical reporting }\end{array}$ & $\begin{array}{l}\text { It developed a } \\
\text { networked } \\
\text { database system } \\
\text { for creating, } \\
\text { storing, and } \\
\text { managing } \\
\text { predefined } \\
\text { radiology report } \\
\text { definitions. }\end{array}$ & $\begin{array}{l}\text { It is a template-type } \\
\text { construct that allows } \\
\text { radiologists to share } \\
\text { standard organ systems or } \\
\text { model-specific templates } \\
\text { dynamically. } \\
\text { It can be triggered from the } \\
\text { printed list of barcodes } \\
\text { while dictating. }\end{array}$ & $\begin{array}{l}\text { Sistrom, } \\
\text { CL; } \\
\text { Honeyman, } \\
\text { JC; } \\
\text { Mancuso, A; } \\
\text { Quisling, } \\
\text { RG [26]. }\end{array}$ \\
\hline
\end{tabular}

Table 5 Operation type software of radiology about the reporting system

\begin{tabular}{|c|c|c|c|c|}
\hline No & $\begin{array}{l}\text { Style Software } \\
\text { Type } \\
\text { OPERATION } \\
\text { Reporting } \\
\text { system } \\
\text { voice } \\
\text { recognition }\end{array}$ & Method & Contribution & Author \\
\hline 4. & $\begin{array}{l}\text { SPIDER the } \\
\text { radiology } \\
\text { reporting } \\
\text { process, } \\
\text { structured entry } \\
\text { of radiology } \\
\text { reports }\end{array}$ & $\begin{array}{l}\text { It contains a } \\
\text { WWW server and } \\
\text { two dedicated } \\
\text { programs. The } \\
\text { WebForm } \\
\text { program converts } \\
\text { the knowledge of } \\
\text { the system into a } \\
\text { graphical WWW } \\
\text { data input form. } \\
\text { The WebReport } \\
\text { program. }\end{array}$ & $\begin{array}{l}\text { It is a structured data entry } \\
\text { in which information can } \\
\text { enter by using } \\
\text { predetermined data } \\
\text { elements and formats - } \\
\text { potentially improving the } \\
\text { radiology reporting process, } \\
\text { structured entries of } \\
\text { radiology reports, }\end{array}$ & $\begin{array}{l}\text { Kahn, CE; } \\
\text { Wang, K; } \\
\text { Bell, DS } \\
\text { [27] }\end{array}$ \\
\hline
\end{tabular}


Table 6 shows the operation type software of radiology about 3D,4D, and AI. The development of telecommunications and computer software led to the development of radiographic image transmission systems. Radiologists can now check X-rays anywhere, and in some cases, this is almost synchronized. It can use the Internet to perform remote imaging such as computed tomography, magnetic resonance imaging, and ultrasound. These systems include systems for transmitting still images and real-time video systems for interactive monitoring through remote radiography. The review workstation (compared to the Picture Archiving and Communication System (PACS)) examines multi-image CT and MRI studies on the iPad tablet [28].

Table 6 Operation type software of radiology about 3D,4D, and AI

\begin{tabular}{|c|c|c|c|c|}
\hline No & $\begin{array}{l}\text { Style } \\
\text { Software } \\
\text { Type } \\
\text { OPERATIO } \\
\mathbf{N} \\
\text { miscellaneou } \\
\mathbf{s}\end{array}$ & Method & Contribution & Author \\
\hline 1 & $\begin{array}{l}\text { STEPanizer } \\
\text { is an } \\
\text { easy-to-use } \\
\text { computer-bas } \\
\text { ed software } \\
\text { tool }\end{array}$ & $\begin{array}{l}\text { A simple tool for stereo } \\
\text { evaluation of digital } \\
\text { images. }\end{array}$ & $\begin{array}{l}\text { STEPanizer is an } \\
\text { easy-to-use, } \\
\text { computer-based } \\
\text { software tool for } \\
\text { stereoscopic evaluation } \\
\text { of digitally captured } \\
\text { images from various } \\
\text { microscopes. }\end{array}$ & $\begin{array}{l}\text { Tschanz, } \\
\text { SA; Burri, } \\
\text { PH; } \\
\text { Weibel, } \\
\text { ER } \\
\text { [29]. }\end{array}$ \\
\hline 2. & $\begin{array}{l}\text { An artificial } \\
\text { neural } \\
\text { network }\end{array}$ & $\begin{array}{l}\text { A distributed network of } \\
\text { computing elements is } \\
\text { modeled on the biological } \\
\text { neural system and } \\
\text { implemented as a } \\
\text { computer software } \\
\text { program. }\end{array}$ & $\begin{array}{l}\text { They successfully } \\
\text { applied to diagnosing } \\
\text { and treating coronary } \\
\text { artery disease and } \\
\text { myocardial infarction, } \\
\text { ECG interpretation and } \\
\text { arrhythmia detection, } \\
\text { and image analysis in } \\
\text { cardiac X-ray and } \\
\text { ultrasonography. }\end{array}$ & $\begin{array}{l}\text { Itchhaporia } \\
\text {, D; Snow, } \\
\text { PB; } \\
\text { Almassy, } \\
\text { RJ; } \\
\text { Oetgen, } \\
\text { WJ [30]. }\end{array}$ \\
\hline $6 .$. & 3D surfaces & It uses to create a & This volume-based & ZUBAL, \\
\hline
\end{tabular}




\begin{tabular}{|c|c|c|c|c|}
\hline & $\begin{array}{l}\text { digital } \\
\text { volumetric } \\
\text { clinical } \\
\text { imaging } \\
\text { instruments }\end{array}$ & $\begin{array}{l}\text { 3-dimensional surface of } \\
\text { human anatomy for use in } \\
\text { a computer database. }\end{array}$ & $\begin{array}{l}\text { software phantom } \\
\text { depicts internal organs } \\
\text { in millimeter resolution } \\
\text { and makes them suitable } \\
\text { for full 3-dimensional } \\
\text { Monte Carlo } \\
\text { simulations. }\end{array}$ & $\begin{array}{l}\text { IG; } \\
\text { HARREL } \\
\text { L, CR } \\
\text { [31]. }\end{array}$ \\
\hline 11. & $\begin{array}{l}\text { 3D } \\
\text { computer-aid } \\
\text { ed, } \\
\text { contact-meth } \\
\text { od } \\
\text { cephalometric } \\
\text { software a } \\
\text { portable 3D } \\
\text { computer-aide } \\
\text { d, } \\
\text { contact-metho } \\
\text { d } \\
\text { cephalometric } \\
\text { system }\end{array}$ & $\begin{array}{l}\text { IT equipped with a newly } \\
\text { developed skull } \\
\text { measurement software for } \\
\text { bedside. }\end{array}$ & $\begin{array}{l}\text { It is used as an adjunct } \\
\text { or alternative to existing } \\
\text { X-ray cephalometric } \\
\text { measurements in the } \\
\text { clinic and as an } \\
\text { epidemiological tool } \\
\text { outside the clinic. }\end{array}$ & $\begin{array}{l}\text { Nagasaka, } \\
\text { S; } \\
\text { Fujimura, } \\
\text { T; } \\
\text { Segoshi, K } \\
\text { [32]. }\end{array}$ \\
\hline 20. & $\begin{array}{l}\text { 4D } \\
\text { Dimension } \\
\text { NSNT v } 1.0 \\
\text { like the } \\
\text { Neoplasms of } \\
\text { the Sinonasal } \\
\text { Tract software } \\
\text { package } \\
\text { (NSNT v 1.0) }\end{array}$ & $\begin{array}{l}\text { It establishes a complete } \\
\text { visual database for } \\
\text { patients with sinus } \\
\text { tumors. }\end{array}$ & $\begin{array}{l}\text { A dedicated, } \\
\text { user-friendly sinus } \\
\text { tumor formation } \\
\text { database facilitates } \\
\text { establishing a } \\
\text { multi-center network } \\
\text { with significant clinical } \\
\text { and research advantages. } \\
\text { Histology and } \\
\text { endoscopic images can } \\
\text { sequence. }\end{array}$ & $\begin{array}{l}\text { Trimarchi, } \\
\text { M; Lund, } \\
\text { VJ; } \\
\text { Nicolai, P; } \\
\text { Pini, M; } \\
\text { Senna, M; } \\
\text { Howard, } \\
\text { DJ , } \\
\text { [33]. }\end{array}$ \\
\hline
\end{tabular}

Table 7 shows the operation type software of radiology about the Teleradiology system.

Intranet helps to optimize the organizational efficiency and cost-effectiveness, and daily work of outpatient and hospital radiology departments. The focus is usually on Internet and Intranet technologies to ensure their continued development [34]. 
Table 7 Operation type software of radiology about Teleradiology system

\begin{tabular}{|c|c|c|c|c|}
\hline No & $\begin{array}{l}\text { Style } \\
\text { Software Type } \\
\text { OPERATION } \\
\text { miscellaneous }\end{array}$ & Method & Contribution & Author \\
\hline 13. & $\begin{array}{l}\text { MASTOS } \\
\text { a software } \\
\text { package }\end{array}$ & $\begin{array}{l}\text { It is a software package } \\
\text { based on the Monte } \\
\text { Carlo method and } \\
\text { intends to use as a } \\
\text { simulation tool in } \\
\text { mammography. }\end{array}$ & $\begin{array}{l}\text { A mammography } \\
\text { simulation tool for } \\
\text { design optimization } \\
\text { studies }\end{array}$ & $\begin{array}{l}\text { Spyrou, G; } \\
\text { Panayiotak } \\
\text { is, G; } \\
\text { Tzanakos, } \\
\text { G } \\
\text { [35]. }\end{array}$ \\
\hline 19. & $\begin{array}{l}\text { PMCT } \\
\text { Post-mortem } \\
\text { computer } \\
\text { tomography } \\
\text { (PMCT) }\end{array}$ & $\begin{array}{l}\text { It is a valuable } \\
\text { procedure that clarifies } \\
\text { how the injury is done } \\
\text { and provides solid } \\
\text { medical evidence, which } \\
\text { is very useful during } \\
\text { litigation and trials. }\end{array}$ & $\begin{array}{l}\text { It is beneficial to get the } \\
\text { essential information to } \\
\text { use } 3 \mathrm{D} \text { rendering, for } \\
\text { example: accurately } \\
\text { depicting the wound } \\
\text { trajectory, identifying } \\
\text { the entrance and exit } \\
\text { wounds, showing the } \\
\text { fracture of the bone, and } \\
\text { the movement of its } \\
\text { fragments in the body. }\end{array}$ & $\begin{array}{l}\text { Maiese, A; } \\
\text { Gitto, L; } \\
\text { De } \\
\text { Matteis, A; } \\
\text { Panebianc } \\
\text { o, V; } \\
\text { Bolino, G } \\
\quad, \\
\text { [36]. }\end{array}$ \\
\hline 21. & $\begin{array}{l}\mathbf{C R} \\
\text { Computed } \\
\text { radiography } \\
(\mathrm{CR})\end{array}$ & $\begin{array}{l}\text { It is a widely used } \\
\text { imaging method }\end{array}$ & $\begin{array}{l}\text { It replaces the regular } \\
\text { screen/film program in } \\
\text { diagnostic radiology } \\
\text { radiodiagnosis. }\end{array}$ & $\begin{array}{l}\text { Zhang, JG; } \\
\text { Huang, } \\
\text { HK [37]. }\end{array}$ \\
\hline 23. & $\begin{array}{l}\text { Teleradiology } \\
\text { Pediatric } \\
\text { Teleradiology }\end{array}$ & $\begin{array}{l}\text { It combines } \\
\text { teleconferencing with a } \\
\text { virtual learning } \\
\text { environment for service } \\
\text { integration, } \\
\text { collaborative research, } \\
\text { and continuing } \\
\text { education in pediatric } \\
\text { radiology. }\end{array}$ & $\begin{array}{l}\text { A new environment for } \\
\text { training, learning and } \\
\text { interactive discussions }\end{array}$ & $\begin{array}{l}\text { Monteiro, } \\
\text { AMV; } \\
\text { Correa, } \\
\text { DG; } \\
\text { Sarmet, } \\
\text { AA; } \\
\text { Cavalcanti } \\
\text {, SA; } \\
\text { Sakuno, T; } \\
\text { Filgueiras, } \\
\text { T; Just, E; }\end{array}$ \\
\hline
\end{tabular}




\begin{tabular}{|c|c|c|c|c|}
\hline & & & & $\begin{array}{l}\text { Santos, M; } \\
\text { Messina, } \\
\text { LA; } \\
\text { Haddad, } \\
\text { AE; } \\
\text { Marchiori, } \\
\text { E [38] }\end{array}$ \\
\hline 24. & $\begin{array}{l}\text { MPCSS } \\
\text { multi personal } \\
\text { computer } \\
\text { storage system } \\
\text { (MPCSS) }\end{array}$ & $\begin{array}{l}\text { It is constructed using } \\
\text { hardware and software. } \\
\text { The image data is } \\
\text { archived from the } \\
\text { primary server to the } \\
\text { personal storage } \\
\text { computer (PC) using the } \\
\text { Neusoft Picture } \\
\text { Archiving and } \\
\text { Communication System } \\
\text { (PACS) and backed up } \\
\text { to the storage PC. }\end{array}$ & $\begin{array}{l}\text { It is a solution for } \\
\text { sea-capacity storage. } \\
\text { PACS storage is much } \\
\text { cheaper than other } \\
\text { high-capacity systems or } \\
\text { devices. It is possible } \\
\text { and suitable for digital } \\
\text { image storage. }\end{array}$ & $\begin{array}{l}\text { Guo, QY; } \\
\text { Hao, FD; } \\
\text { Duan, XL; } \\
\text { Xie, XQ; } \\
\text { Liao, W } \\
\text { [39]. }\end{array}$ \\
\hline 25. & RODOS & $\begin{array}{l}\text { Its distributed database, } \\
\text { geographic information } \\
\text { system RoGIS, online } \\
\text { connections to } \\
\text { radiology and } \\
\text { meteorological } \\
\text { networks, and software } \\
\text { environments for } \\
\text { integrating external } \\
\text { programs into RODOS } \\
\text { systems }\end{array}$ & $\begin{array}{l}\text { It provides tools for } \\
\text { processing and } \\
\text { managing various types } \\
\text { of information, } \\
\text { including meteorology, } \\
\text { radiology, economics, } \\
\text { emergency operations, } \\
\text { and countermeasures, } \\
\text { rules, preferences, facts, } \\
\text { maps, and statistics. }\end{array}$ & $\begin{array}{l}\text { Schule, O; } \\
\text { Rafat, M } \\
{[40] .}\end{array}$ \\
\hline
\end{tabular}

Table 8 shows the education type of radiology software. Computers have greatly facilitated the processing and storage of radiological information. Manufacturers of radiology information systems (RIS) increasingly connect their products to other computers (for example, hospital information systems). However, the demand for RIS and digital radiology equipment continues to increase, so images (such as X-rays of the chest and bones) will automatically mark the data marked by the technician, thereby eliminating redundant work and reducing appearance marking errors. Data for patients 
with increased radiographic consistency [41]. The artificial neural network is a kind of artificial computer intelligence, which has been a research hotspot in the past ten years [30]. Despite the enthusiasm for software and continuous improvement, some studies clearly show that medical education is superior to traditional methods [5]. These methods are aimed at human-centered social cognitive engineering. It integrates software and tasks. Knowledge and organizational engineering have been improved and tested through developing computer systems to support training and professional work [42]. Although digital technology plays an increasingly important role in radiology, teaching documents are widespread in radiology [43]. Radiologists may be interested in different free (open source) software available via the Internet. Web-based programs provide different levels of radiological anatomy and practical difficulties, allowing users to test and build their knowledge of radiation [45].

Table 8 Education type of radiology software

\begin{tabular}{|c|c|c|c|c|}
\hline No & $\begin{array}{l}\text { Style } \\
\text { Software Type } \\
\text { EDUCATION }\end{array}$ & Method & Contribution & Author \\
\hline 1. & $\begin{array}{l}\text { PACE teaching } \\
\text { system }\end{array}$ & $\begin{array}{l}\text { It creates an } \\
\text { image-based } \\
\text { e-learning file to } \\
\text { replace the } \\
\text { collection of } \\
\text { printed film } \\
\text { images. } \\
\text { Integrate } \\
\text { multimedia } \\
\text { teaching and } \\
\text { reference databases } \\
\text { in a PACS } \\
\text { environment. }\end{array}$ & $\begin{array}{l}\text { It allows doctors to create } \\
\text { reference databases } \\
\text { directly from the clinical } \\
\text { case reviews on the PACS } \\
\text { diagnostic workstation for } \\
\text { teaching and research. }\end{array}$ & $\begin{array}{l}\text { Rosset, A; } \\
\text { Ratib, O; } \\
\text { Geissbuhler, } \\
\text { A; Vallee, } \\
\text { JP } \\
\text { [46]. }\end{array}$ \\
\hline 2. & $\begin{array}{l}\text { A software } \\
\text { tool-ViewDEX } \\
\text { (Viewer for } \\
\text { Digital } \\
\text { Evaluation of } \\
\text { X-ray images) }\end{array}$ & $\begin{array}{l}\text { It is developed in } \\
\text { Java, making it run } \\
\text { on almost all } \\
\text { computers. }\end{array}$ & $\begin{array}{l}\text { It is designed to handle } \\
\text { many types of research, } \\
\text { such as visual grade } \\
\text { analysis (VGA), standard } \\
\text { image score (ICS), and } \\
\text { receiver operating } \\
\text { characteristics (ROC). } \\
\text { A software tool for }\end{array}$ & $\begin{array}{l}\text { Borjesson, } \\
\mathrm{S} ; \\
\text { Hakansson, } \\
\text { M; Bath, M; } \\
\text { Kheddache, } \\
\text { S; Svensson, } \\
\text { S; Tingberg, } \\
\text { A; Grahn, }\end{array}$ \\
\hline
\end{tabular}




\begin{tabular}{|c|c|c|c|c|}
\hline & & & $\begin{array}{l}\text { improving the efficiency } \\
\text { of radiologists' } \\
\text { performance studies }\end{array}$ & $\begin{array}{l}\text { A; Ruschin, } \\
\text { M; Hemdal, } \\
\text { B; Mattsson, } \\
\text { S; Mansson, } \\
\text { LG [47]. }\end{array}$ \\
\hline 3. & $\begin{array}{l}\text { Radiologist } \\
\text { multimedia } \\
\text { publishing } \\
\text { software }\end{array}$ & $\begin{array}{l}\text { It bases on the } \\
\text { Internet, the World } \\
\text { Wide Web, Mosaic, } \\
\text { and Wide Area } \\
\text { Information Server } \\
\text { software } \\
\text { technologies, all of } \\
\text { which are in the } \\
\text { public domain. }\end{array}$ & $\begin{array}{l}\text { This networked } \\
\text { multimedia textbook } \\
\text { approach to the global } \\
\text { distribution of multimedia } \\
\text { radiology information } \\
\text { brings today's radiologists } \\
\text { the benefits of multimedia } \\
\text { publishing on the Internet. }\end{array}$ & $\begin{array}{l}\text { Dalessandro } \\
\text {, Mp; Lacey, } \\
\text { D1; Galvin, } \\
\text { Jr; Erkonen, } \\
\text { We; Santer, } \\
\text { Dm } \\
\text { [48]. }\end{array}$ \\
\hline 4. & $\begin{array}{l}\text { Teaching file } \\
\text { software } \\
\text { (TF-Web) }\end{array}$ & $\begin{array}{l}\text { It was developed } \\
\text { for the World Wide } \\
\text { Web and used in } \\
\text { conjunction with } \\
\text { locally produced } \\
\text { programs for } \\
\text { importing images. }\end{array}$ & $\begin{array}{l}\text { It can access both local } \\
\text { and remote (Internet) } \\
\text { networks. Another } \\
\text { requirement is that it is } \\
\text { easy to view existing } \\
\text { cases and add new ones. }\end{array}$ & $\begin{array}{l}\text { Wallis, Jw; } \\
\text { Miller, Mm; } \\
\text { Miller, Tr; } \\
\text { VreelanD } \\
\text { [49]. }\end{array}$ \\
\hline 5. & $\begin{array}{l}\text { An automated } \\
\text { Computerized, } \\
\text { the } \\
\text { categorization } \\
\text { of narrative text } \\
\text { radiograph } \\
\text { reports, is } \\
\text { illustrated. }\end{array}$ & $\begin{array}{l}\text { A text search } \\
\text { algorithm uses } \\
\text { dividing a } \\
\text { radiographic report } \\
\text { into a fracture, } \\
\text { typical, neither } \\
\text { regular nor fracture. }\end{array}$ & $\begin{array}{l}\text { It is a potent tool for } \\
\text { cost-benefit research, } \\
\text { healthcare policy, } \\
\text { operational assessment, } \\
\text { and quality control. }\end{array}$ & $\begin{array}{l}\text { Thomas, BJ; } \\
\text { Ouellette, H; } \\
\text { Halpern, EF; } \\
\text { Rosenthal, } \\
\text { DI [50]. }\end{array}$ \\
\hline 6. & $\begin{array}{l}\text { A digital teaching } \\
\text { file }(\mathbf{D T F}), \\
\text { Computer-based } \\
\text { training }(\mathrm{CBT}) \text { in } \\
\text { radiology }\end{array}$ & $\begin{array}{l}\text { DTF is built using } \\
\text { established Internet } \\
\text { tools and integrated } \\
\text { into heterogeneous } \\
\text { PACS/RIS } \\
\text { environments. }\end{array}$ & $\begin{array}{l}\text { It helps quickly transfer } \\
\text { selected images } \\
\text { (DICOM_Send) to the } \\
\text { DTF during interpretation } \\
\text { and access to the DTF } \\
\text { application anytime, } \\
\text { anywhere. }\end{array}$ & $\begin{array}{l}\text { Trumm, C; } \\
\text { Dugas, M; } \\
\text { Wirth, S; } \\
\text { Treitl, M; } \\
\text { Lucke, A; } \\
\text { Kuttner, B; } \\
\text { Pander, E; } \\
\text { Clevert, } \\
\text { DA; Glaser, }\end{array}$ \\
\hline
\end{tabular}




\begin{tabular}{|c|c|c|c|c|}
\hline & & & & $\begin{array}{l}\text { C; Reiser, M } \\
\text { [51]. }\end{array}$ \\
\hline 7. & $\begin{array}{l}\text { 3-dimensional } \\
\text { (3D) printing }\end{array}$ & $\begin{array}{l}\text { It can create a } \\
\text { personalized/patien } \\
\text { t-specific liver 3D } \\
\text { physical model } \\
\text { from clinical } \\
\text { radiology studies } \\
\text { for surgical } \\
\text { residency } \\
\text { education. }\end{array}$ & $\begin{array}{l}\text { cant use to develop } \\
\text { low-cost } \\
\text { personalized/patient-spe } \\
\text { cific liver 3D models for } \\
\text { clinical residency } \\
\text { education through } \\
\text { clinical radiology } \\
\text { research. }\end{array}$ & $\begin{array}{l}\text { atson, RA,A } \\
\text { [52]. }\end{array}$ \\
\hline 8. & $\begin{array}{l}\text { Integrating } \\
\text { interactive } \\
\text { three-dimensiona } \\
1 \text { post-processing } \\
\text { software into } \\
\text { undergraduate } \\
\text { radiology } \\
\text { teaching }\end{array}$ & $\begin{array}{l}\text { Collaborative } \\
\text { improvement in } \\
\text { visual space and } \\
\text { radiology skills is a } \\
\text { promising } \\
\text { approach. }\end{array}$ & $\begin{array}{l}\text { It can effectively reduce } \\
\text { students' lack of image } \\
\text { interpretation. } \\
\text { It can improve diagnostic } \\
\text { skills and visual space } \\
\text { capabilities. }\end{array}$ & $\begin{array}{l}\text { Rengier, F; } \\
\text { Hafner, MF; } \\
\text { Unterhinnin } \\
\text { ghofen, R; } \\
\text { Nawrotzki, } \\
\text { R; Kirsch, J; } \\
\text { Kauczor, } \\
\text { HU; Giesel, } \\
\text { FL[53]. }\end{array}$ \\
\hline 9. & $\begin{array}{l}\text { RadNotes: A } \\
\text { novel software } \\
\text { development tool } \\
\text { for radiology } \\
\text { education }\end{array}$ & $\begin{array}{l}\text { It enables doctors } \\
\text { to develop } \\
\text { textbooks that } \\
\text { combine text and } \\
\text { images in an } \\
\text { innovative, highly } \\
\text { available format. }\end{array}$ & $\begin{array}{l}\text { Software development } \\
\text { tools are for radiology } \\
\text { education that does not } \\
\text { require programming } \\
\text { expertise or the help of a } \\
\text { software engineer. }\end{array}$ & $\begin{array}{l}\text { Baxter, AB; } \\
\text { Klein, JS; } \\
\text { Oesterle, } \\
\text { EV , [54]. }\end{array}$ \\
\hline 10 & $\begin{array}{l}\text { Artificial } \\
\text { intelligence and } \\
\text { deep learning }\end{array}$ & $\begin{array}{l}\text { Track the use of } \\
\text { radiology } \\
\text { computers, from } \\
\text { management } \\
\text { functions to image } \\
\text { acquisition, storage, } \\
\text { and reporting, to } \\
\text { trying to improve } \\
\text { diagnosis as early } \\
\text { as possible, }\end{array}$ & $\begin{array}{l}\text { Imagine new areas that } \\
\text { might use in exam } \\
\text { interpretation. }\end{array}$ & $\begin{array}{l}\text { Ray } \\
\text { CodyMayoJ } \\
\text { essicaLeung } \\
{[73]}\end{array}$ \\
\hline 11 & Proton PACS & With & It is uniquely engineered & [74] \\
\hline
\end{tabular}




\begin{tabular}{|l|l|l|l|}
\hline & $\begin{array}{l}\text { state-of-the-art } \\
\text { storage, viewing } \\
\text { and voice } \\
\text { recognition } \\
\text { features, }\end{array}$ & $\begin{array}{l}\text { to eliminate downtime } \\
\text { and increase workflow } \\
\text { efficiency. }\end{array}$ & \\
\end{tabular}

\section{Research method}

A historical review of this research application is based on an understanding of trends and radiology IT's innovative contributions. This study aimed to analyze all radiology software publications in the Science Citation Index (SCI). From 1991 to July 2021, SCI was used to search for publications systematically. The selected file includes the radiology software as part of the title, abstract, or keyword. Analysis parameters include authorship, international cooperation mode, magazine, language, file type, research address, reference count, and reprinted author address. The citation analysis is based primarily on the Journaling Citation Report (JCR) and the impact factor defined in each publication citation (CPP) and is used to assess the effect of the journal relative to the entire field and describes it as the ratio. The average per publication quotes at a given time. Also, historical methods have been applied to the study of radiology software. This practice shows that historical phenomena can be costly and complicated. We can raise our awareness by reviewing and investigating the background and development of time, location, and events. From July 1991 to 2021, SCI initiated and used historical methods to develop software radiology publications.

\section{IV.Research finding and discussion}

\section{Challenges: Privacy, data security}

In the Virtual Radiology Environment (VRE), the information to be protected embeds in three main information components:

(1) Patient information includes fields in the Digital Imaging and Medical Communications (DICOM) format. Patient information is located in the Digital Imaging Mesh Image Archiving and Communication System (DIN-PACS) network in the data vault system, including (a) patient demographic information; (b) patient information; (c) patient image can be by X-ray, computed tomography (CT), magnetic resonance imaging (MRI), and ultrasound (US); (c) previous patient images and related patient medical history.

(2) Meta-manager information to be protected consists of multiple data objects. This information will be distributed to the Meta-Manager node, including (a) radiologist programs; (b) radiologist programs; (c) radiologist programs; (c) radiologist programs; Radiologist program; (c) radiologist program; (b) list of modal words; (c) route case information; (d) information on DIN-PACS and integrated health systems, and meta-management management 
and safety Information; (e) Patient case data.

(3) VRE requires access control and communication security to control who uses the VRE and meta-manager functions and protects messages between VRE elements [68].

\section{Contributions:}

\section{CT:}

The precise CT technology of the spine covers the smallest area required to answer clinical questions, and individual patients significantly impact the risk of cancer. Cancer risk is decisive, so it is necessary to consider spinal CT imaging based on the total radiation risk over the patient's lifetime [55]. Radiation diagnostics, such as traditional radiography, fluoroscopy, and computed tomography (CT), will continue to bring significant benefits to modern medical care [57].

PACE: It determines the cost of the difference between film-based radiology and the hospital's image archiving and communication system (PACS). If a hospital-wide PACS is implemented in a short period, it will immediately convert to digital movies and archives. The net present value of the Pacs business is $\$ 1,598,698$, and the net current worth of the film business is $\$ 208,856$, with a net savings of $\$ 485,157$. The payback period is four years. The cost of computer radiography and imaging boards accounts for $40 \%$ of the initial capital expenditures of Pacs, followed by computer hardware (30\%) and software (9\%). Explain that implementing Pacs inside the hospital can save costs. The Internet can quickly distribute information to distant users through various computers, making it a definite candidate for electronic medical record system technology solutions. Second-generation Internet technologies, such as the ones described in this article-XML (Extensible Markup Language), XSL (Extensible Style Language), dom (Archive Object Model), CSS (Cascading Style Sheets). Javascript and JavaBeans can significantly reduce the complexity of distributed medical system development [69].

Computer applications in radiology are rapidly evolving and linked to the gradual improvement of hardware, software, and methods. Significant improvements in engineering workstation graphics and computational efficiency have helped to visualize in terms of computer hardware. Substantial changes in networking, storage, and display technologies play an essential role in influencing applications. It reports that it can use 3D digitizers and rapid prototyping methods (such as stereolithography) to locate 3D points and images and object rendering in real-time. The software has made significant progress using a menu-driven or point-and-click user interface, a data flow language, or an application package for a complete turnkey application. This year, imaging methods using advanced computer technology are new technologies, including ct, MR imaging, digital imaging, biomagnetism, and optical 
distance sensing. Image processing for multimodal fusion or image registration, visualization, reconstruction, and image quantification reports in various conferences and publications - a new computer approach proposed for custom orthopedic implants and improved imaging techniques [70].

A smartphone is a telephone device to browse, navigate, and run small computer programs called applications. A tablet or tablet is a fully functional stand-alone computer with a thin LCD to control and input data using the screen itself. To illustrate how experts, radiographers, and residents can diagnose imaging using smartphones and tablets, you can use mobile apps with iTunes, Android Market, BlackBerry App World, and Windows Phone Market Diagnostic Imaging. The following terms apply to search strategies: (1) radiology, (2) X-ray, (3) ultrasound, (4) MRI, (5) CT, (6) technician, and (7) nuclear medicine. Smartphones and tablets offer new opportunities for diagnostic imaging practitioners - these easy-to-use devices are equipped with a display for good reading. The development of research techniques, image processing, workstation monitoring, and analysis tools in the field of radiology is enormous, and the need for valuable tools to evaluate and optimize the quality of images and surveys is significant [7]. Medical imaging is primarily in radiology, but with the advent of virtual pathology and telemedicine, imaging technology has expanded in healthcare companies. As new imaging technologies evolve, they must evaluate them to assess patient care's impact and benefits [72].

\section{V.Conclusion}

This study aimed to explore the trends, predictions, and challenges of informatics and historical trend analysis. The development of emerging radiology information technology has made the global radiology business environment a dynamic market. The hospital will continue to face new radiological technology and competition and increasingly complex patient expectations. The basic principle of this research is that information technology is increasing almost every day, and we must continuously seek new ways to use it to create more resources. In light of this, developing new ways of thinking for radiology organizations, workflows, and business models is increasingly important. Radiology organizations not only use intellectual capital and information technology to improve their operational deficiencies, but radiology directors are also committed to addressing ongoing operational crises. They invest resources and knowledge in reconfiguring and creating innovative structures and systems to overcome problems and pursue more efficient operations.

This study used a combination of historical review and data analysis. This study aimed to analyze all radiology software publications in the Science Citation Index (SCI). From 1991 to July 2021, SCI was used to search for publications systematically.

The contribution of this research is that radiology managers recognize that the use of new information technologies is critical to survival in a competitive environment. [5] From the perspective of academic contribution, from discovering the theory of innovation diffusion to 
finding embedded academic research, it directly guides enterprises to improve existing machines, software, or operational errors, innovate technologies, provide better services, and enhance the quality of service and performance.

\section{Reference}

[1] Goyal, N; Jain, N; Rachapalli, V, Ergonomics in radiology ， Clinical

$\begin{array}{lllllllll}\text { Radiology , } & \text { V. } 64 \quad, \quad \text { I. } 2 & 2 & \text {, } & \text { PP. } & 119 & - & 126\end{array}$

[2] Edwards, SP ， Computer-Assisted Craniomaxillofacial Surgery, Oral And

Maxillofacial Surgery Clinics Of North America, $\quad$ V. 22 , $\quad$ I. $1 \quad$, PP. $117-\quad+\quad, 2010$

[3] Vidal, FP; Bello, F; Brodlie, KW; John, NW; Gould, D; Phillips, R; Avis, NJ; Hirsch, T, Principles and applications of computer graphics in medicine, Computer Graphics

Forum, V. 25, I. 1, PP. 113 - 137,2006

[4] Sistrom, C, The socioeconomic aspects of information technology for health care with emphasis on radiology ， Academic Radiology , V. 12 ， I. 4 , PP. 431 - 443,2005

[5] Letterie, GS, Medical education as a science: The quality of evidence for computer-assisted instruction, American Journal Of Obstetrics And Gynecology, V.

188, I. 3, PP. 849 - 853,2003

[6] Perriss, RW; Graham, RNJ; Scarsbrook, AF , Understanding the internet, website design and intranet development: a primer for radiologists , Clinical

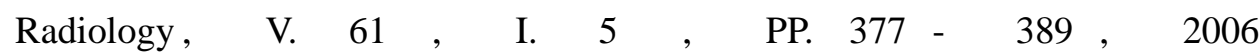

[7] Hakansson, M; Svensson, S; Zachrisson, S; Svalkvist, A; Bath, M; Mansson, LG, ViewDEX: an efficient and easy-to-use software for observer performance studies, Radiation Protection Dosimetry, V. 139, I. 13, PP. 42 - $51 \quad$ ～ 2010

[8] Kakeda, S; Moriya, J; Sato, H; Aoki, T; Watanabe, H; Nakata, H; Oda, N; Katsuragawa, $\mathrm{S}$; Yamamoto, K; Doi, K, Improved detection of lung nodules on chest radiographs using a commercial computer-aided diagnosis system, American Journal Of Roentgenology, V.

182, I. 2, PP. 505 - $510 ， 2004$

[9] Pietka, E; Kawa, J; Badura, P; Spinczyk, D, Open architecture computer-aided diagnosis system , Expert Systems, V. 27 , I. 1 , PP. 17 $39 \quad, \quad 2010$

[10] Teague, SD; Trilikis, G; Dharaiya, E , $\quad$ Lung Nodule Computer-Aided Detection as a Second Reader: Influence on Radiology Residents ， Journal Of Computer Assisted Tomography , $\quad$ V. 34 , I. $1 \quad$, PP. $35 \quad-\quad 39 \quad, \quad 2010$ [11] Kirchgeorg, MA; Prokop, M ， Increasing spiral CT benefits with postprocessing applications ， European Journal Of Radiology , V. $28 \quad$, I. 1 , PP. $39-54 \quad, \quad 1998$

[12] Thali, MJ; Taubenreuther, U; Karolczak, M; Braun, M; Brueschweiler, W; Kalender, WA; 
Dirnhofer, R, Forensic neuroradiology: Micro-computed tomography (micro-CT) and analysis of patterned injuries inside of bone, Journal Of Forensic Sciences, V. 48, I. 6, PP. $1336-\quad 1342,2003$

[13] Henri, CJ; Rubin, RK; Cox, RD; Bret, PM, Design and implementation of World Wide Web-based tools for image management in computed tomography, magnetic resonance imaging, and ultrasonography, Journal Of Digital Imaging, $\quad$ V. $\quad 10, \quad$ I. $\quad 3, \quad$ PP. $77 \quad-79 \quad, \quad 1997$

[14] Friedkin, AM; Weadock, WJ ， Creation of annotated cine ultrasound videos from multiframe DICOM files ， International Journal Of Computer Assisted Radiology And

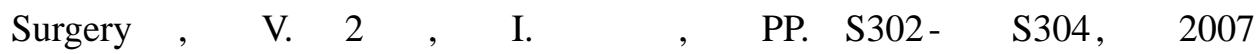

[15] Parker, GJM; Suckling, J; Tanner, SF; Padhani, AR; Husband, JE; Leach, MO ,

MRIW: Parametric analysis software for contrast-enhanced dynamic MR imaging in cancer , Radiographics , V. 18 , I. 2 , PP. 497 - 506 , 1998

[16] Blanco, RT; Ojala, R; Kariniemi, J; Perala, J; Niinimaki, J; Tervonen, O,

Interventional and intraoperative MRI at low field scanner - a review, European Journal

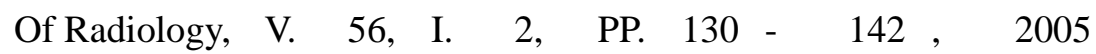

[17] Arenson, RL; Chakraborty, DP; Seshadri, SB; Kundel, HL ， The digital imaging workstation (Reprinted from Radiology, vol 176, pg 303-315, 1990) , Journal Of Digital Imaging, $\quad$ V. 16 , I. 1 , PP. 142 - $162 ， 2003$ [18] Tam, MDBS ， Building Virtual Models by Postprocessing Radiology Images: A Guide for Anatomy Faculty ～， Anatomical Sciences Education ， V.3 ,I. 5,PP. 261 - 266,2010

[19] Rosset, A; Muller, H; Martins, M; Dfouni,N; Vallee,JP; Ratib, O , Casimage project - A digital teaching files authoring environment ， Journal Of Thoracic Imaging ,V.19,I.2,PP.103-108,2004

[20] Branstetter, BF , Basics of imaging informatics: Part 1, RADIOLOGY , V. 243 , I. 3 , PP. 656 - 667,2007

[21] Lambrecht, Jt; Hammer, B; Jacob, Al; Schiel, H; Hunziker, M; Kreusch, T; Kliegis, U , Individual Model Fabrication In Maxillofacial Radiology ， Dentomaxillofacial

Radiology, V. 24 , $\quad$ I. $3 \quad$, $\quad$ PP. 147 - 154 , 1995

[22] Yoon, HJ; Zheng, B; Sahiner, B; Chakraborty, DP ～， Evaluating computer-aided detection algorithms , Medical Physics , $\quad$ V. 34 , I. 6 , PP. 2024 - 2038, 2007

[23] Callaway, EC; Sweet, CF; Siegel, E; Reiser, JM; Beall, DP , Speech recognition interface to a hospital information system using a self-designed visual basic program: Initial experience, Journal Of Digital Imaging, $\quad$ V. 15 , I. 1 , PP. 43 $53, \quad 2002$ 
[24] Schwartz, LH; Kijewski, P; Hertogen, H; Roossin, PS; Castellino, RA, Voice recognition in radiology reporting , American Journal Of Roentgenology , V.
169
I.
PP. 27
29 ,
1997

[25] Lee, YH; Song, HT; Suh, JS ～， Quantitative Computed Tomography (QCT) as a Radiology Reporting Tool by Using Optical Character Recognition (OCR) and Macro

Program , Journal Of Digital Imaging, $\quad$ V. 25 , I. $6 \quad$, PP. 815 $818, \quad 2012$

[26] Sistrom, CL; Honeyman, JC; Mancuso, A; Quisling, RG ， Managing predefined templates and macros for a departmental speech recognition system using common software, Journal Of Digital Imaging, $\quad$ V. 14 , $\quad$ I. $3 \quad$, $\quad$ PP. 131 - 141 , 2001

[27] Kahn, CE; Wang, K; Bell, DS ， Structured entry of radiology reports using World Wide Web technology , Radiographics , V. 16 , I. 3 , PP. 683 - 691,1996

[28] John, S; Poh, ACC; Lim, TCC; Chan, EHY; Chong, LR, The iPad Tablet Computer for Mobile On-Call Radiology Diagnosis? Auditing Discrepancy in CT and MRI Reporting,

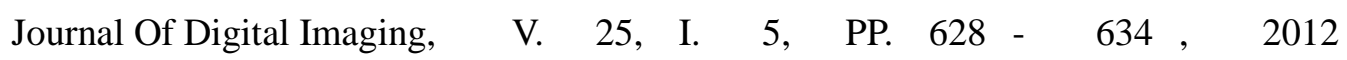
[29] Tschanz, SA; Burri, PH; Weibel, ER , A simple tool for stereological assessment of digital images: the STEPanizer ， Journal Of Microscopy ， V. 243 ， I. 1 PP. $47 \quad-59 \quad, \quad 2011$

[30]Itchhaporia, D; Snow, PB; Almassy, RJ; Oetgen, WJ , Artificial neural networks: Current status in cardiovascular medicine , Journal Of The American College Of

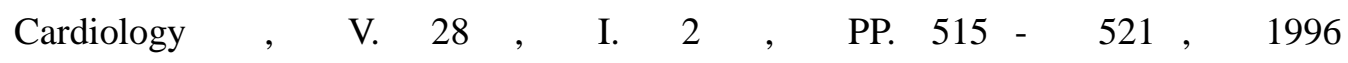

[31] Zubal, Ig; Harrell, Cr, Voxel-Based Monte-Carlo Calculations Of Nuclear-Medicine Images And Applied Variance Reduction Techniques , Image And Vision Computing ,
V. 10
I. 6 ,
PP. 342 -
348 ,
1992

[32] Nagasaka, S; Fujimura, T; Segoshi, K, Development of a non-radiographic cephalometric system, $\quad$ European Journal Of Orthodontics $\quad, \quad$ V. 25 , I. 1 PP. $77 \quad-85 \quad, \quad 2003$

[33] Trimarchi, M; Lund, VJ; Nicolai, P; Pini, M; Senna, M; Howard, DJ, Software application - Database for the collection and analysis of clinical data and images of neoplasms of the sinonasal tract, Annals Of Otology Rhinology And Laryngology, V. 113, I. 4, PP. 335 - 337,2004

[34] Knopp, MV; von Hippel, GM; Koch, T; Knopp, MA , Intranet applications in radiology, Radiologe, V. 40 , I. 1 , $\quad$ PP. 78 - 82 , 2000

[35] Spyrou, G; Panayiotakis, G; Tzanakos, G ， MASTOS: Mammography simulation tool for design optimization studies ， Medical Informatics And The Internet In Medicine 


\section{, V. 25 , I. 4 , PP. 275 - 293,2000}

[36] Maiese, A; Gitto, L; De Matteis, A; Panebianco, V; Bolino, G ～， Post mortem computed tomography: Useful or unnecessary in gunshot wounds deaths? Two case reports ,

Legal Medicine, $\quad$ v. 16 , i. 6 , pp. 357 - 363,2014

[37] Zhang, JG; Huang, HK ， Multilevel adaptive process control of acquisition and post-processing of computed radiographic images in picture archiving and communication system environment ， Computerized Medical Imaging And Graphics ， V. 22 , I. 1 , PP. 31 - 40 , 1998

[38] Monteiro, AMV; Correa, DG; Sarmet, AA; Cavalcanti, SA; Sakuno, T; Filgueiras, T; Just, E; Santos, M; Messina, LA; Haddad, AE; Marchiori, E, Telemedicine and Pediatric Radiology: A New Environment for Training, Learning, and Interactive Discussions ,

Telemedicine And E-Health ， V. 17 , I. 10 , PP. 753 756,2011

[39] Guo, QY; Hao, FD; Duan, XL; Xie, XQ; Liao, W ～， Multi personal computer storage system: solution of sea capacity PACS storage, Chinese Medical Journal , V. 116 , I. 5 , PP. 650 - 653,2003

[40] Schule, O; Rafat, M ， The software framework of RODOS ， Radiation

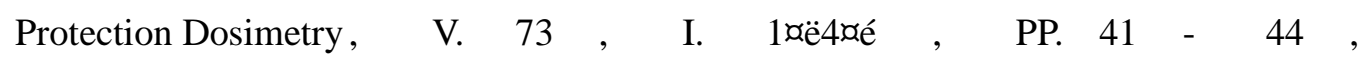
1997

[41] Frank, Ms; Stewart, Bk; Rowberg, Ah, Use Of Data In A Radiology Information-System For Labeling Computed Radiographs - An Interface To Connect The 2 Systems , American Journal Of Roentgenology , V. 164 , I. 3 , PP. 745 - 747,1995

[42] Sharples, M; Jeffery, N; du Boulay, JBH; Teather, D; Teather, B; du Boulay, GH , Socio-cognitive engineering: A methodology for the design of human-centred technology , European Journal Of Operational Research, V. 136 , I. 2 , PP. 310 - 323,2002

[43] Henderson, B; Camorlinga, S; DeGagne, JC , A cost-effective web-based teaching file system , Journal Of Digital Imaging, V. 17 , I. 2 , PP. 87 - $91 \quad, \quad 2004$

[44] Scarsbrook, AF , Open-source software for radiologists: a primer , Clinical

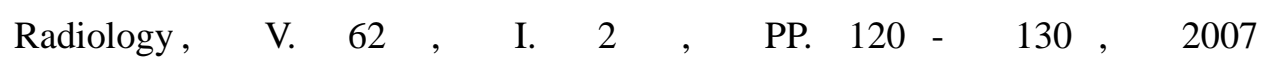

[45] Grunewald, M; Heckemann, RA; Gebhard, H; Lell, M; Bautz, WA ～， COMPARE Radiology: Creating an interactive Web-based training program for radiology with multimedia authoring software , Academic Radiology, $\quad$ V. $10 \quad$, I. 5 , PP. 543 - 553 , 2003

[46] Rosset, A; Ratib, O; Geissbuhler, A; Vallee, JP , Integration of a multi-media teaching and reference database in a PACS environment , Radiographics , V. 
22 , I. 6 , PP. $1567-\quad 1577,2002$

[47]Borjesson, S; Hakansson, M; Bath, M; Kheddache, S; Svensson, S; Tingberg, A; Grahn, A; Ruschin, M; Heimdal, B; Mattsson, S; Mansson, LG, A software tool for increased efficiency in observer performance studies in radiology, Radiation Protection Dosimetry, V. 114, I. 13, PP. 45 - 52,2005

[48] Dalessandro, Mp; Lacey, Dl; Galvin, Jr; Erkonen, We; Santer, Dm, The Networked Multimedia Textbook - Distributing Radiology Multimedia Information Across The Internet, American Journal Of Roentgenology, V. $\quad 163$, I. $\quad 5, \quad$ PP. 1233 - 1237 , 1994

[49] Wallis, Jw; Miller, Mm; Miller, Tr; Vreeland, Th , An Internet-Based

Nuclear-Medicine Teaching File , Journal Of Nuclear Medicine ， $\quad$ V. $36 \quad$ I. $8 \quad$ PP. 1520 - 1527, 1995

[50] Thomas, BJ; Ouellette, H; Halpern, EF; Rosenthal, DI, Automated computer-assisted categorization of radiology reports , American Journal Of

Roentgenology , V. 184 , I. 2 , PP. 687 - 690 , 2005

[51] Trumm, C; Dugas, M; Wirth, S; Treitl, M; Lucke, A; Kuttner, B; Pander, E; Clevert, DA; Glaser, C; Reiser, M ， Digital teaching file. Concept, implementation, and experiences in a university setting , Radiologe, $\quad$ V. 45 , I. 8 , $\quad$ PP. 724 734,2005

[52] Watson, RA ， A Low-Cost Surgical Application of Additive Fabrication , Journal Of Surgical Education , $\quad$ V. 71 , I. 1 , $\quad$ PP. 14 $17 \quad, \quad 2014$

[53] Regnier, F; Hafner, MF; Unterhinninghofen, R; Nawrotzki, R; Kirsch, J; Kauczor, HU; Giesel, FL, Integration of interactive three-dimensional image post-processing software into undergraduate radiology education effectively improves diagnostic skills and visual-spatial ability, European Journal Of Radiology, V. $\quad 82 ， \quad$ I. $\quad$ 8， $\quad$ PP. 1366 1371, 2013

[54] Baxter, AB; Klein, JS; Oesterle, EV ， RadNotes: A novel soft ware development tool for radiology education , Radiographics , V. 17 , I. 3 , PP. 761 - 767,1997

[55] Kuhnigk, JM; Dicken, V; Zidowitz, S; Bornemann, L; Kuemmerlen, B; Krass, S; Peitgen, HO; Yuval, S; Jend, HH; Rau, WS; Achenbach, T, New tools for computer assistance in thoracic CT Part 1. Functional analysis of lungs, lung lobes, and bronchopulmonary segments , Radiographics , V. 25 , I. 2 , PP. 525 - 536 , 2005

[56] Bick, U; Lenzen, H , PACS: the silent revolution European Radiology , V. 9 , I. 6 , PP. 1152 - 1160,1999

[57] Osei, EK; Barnett, R , Software for the estimation of organ equivalent and effective 
doses from diagnostic radiology procedures , Journal Of Radiological Protection ,

$$
\text { V. } 29 \text {, I. } 3 \text {, PP. } 361 \text { - } 376,2009
$$

[58] Fang, YC; Yang, MC; Hsueh, YS ， Financial assessment of a picture archiving and communication system implemented all at once , Journal Of Digital Imaging, V.

$$
19 \text {, I. } \quad \text { PP. } 44-51,2006
$$

[59] Yamazaki, A; Liu, P; Cheng, WC; Badano, A ， Image Quality Characteristics of Handheld Display Devices for Medical Imaging, Plos One , $\quad$ V. $8 \quad$, I.

$$
11 \text {, PP. - , } 2013
$$

[60] Engelmann, U; Schroeter, A; Schwab, M; Eisenmann, U; Vetter, M; Lorenz, K; Quiles, J; Wolf, I; Evers, H; Meinzer, HP, Borderless Teleradiology with CHILI,Journal Of Medical

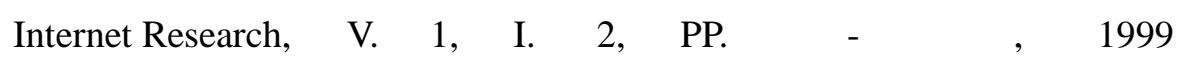

[61] Choudhri, AF; Chatterjee, AR; Javan, R; Radvany, MG; Shih, G , Security Issues for Mobile Medical Imaging: A Primer ， Radiographics , $\quad$ V. 35 , $\quad$ I. 6 PP. 1814 - $1824, \quad 2015$

[62] Lasko, TA; Bhagwat, JG; Zou, KH; Ohno-Machado, L, The use of receiver operating characteristic curves in biomedical informatics, Journal Of Biomedical Informatics, V. 38, I. 5, PP. 404 - 415 ， 2005 [63] Stern, Ej; Westenberg, L ， Copyright Law And Academic Radiology - Rights Of Authors And Copyright Owners And Reproduction Of Information ， American Journal Of Roentgenology ， V. $164 ， \quad$ I. $\quad 5 \quad ， \quad$ PP. 1083 - 1088 , 1995 [64] Baker, GR, Localization: conventional and CT simulation ， British Journal Of Radiology, V. 79 , I. I. ， PP. S36 - S49 , 2006

[65] Flanders, AE; Wiggins, RH; Gozum, ME , Handheld computers in radiology , Radiographics , V. 23 , I. 4 , PP. 1035- 1047, 2003

[66] Prevrhal, S; Shepherd, JA; Smith-Bindman, R; Cummings, SR; Kerlikowske, K, Accuracy of mammographic breast density analysis: Results of formal operator training, Cancer Epidemiology Biomarkers \& Prevention, V. 11, I. 11, PP. 1389 $1393, \quad 2002$

[67] Lou, SL; Huang, HK; Arenson, RL ， Workstation design - Image manipulation, image set handling, and display issues , Radiologic Clinics Of North America, V. 34 , I. 3 , PP. 525 - \& , 1996

[68] Martinez, R; Cole, C; Rozenblit, J; Cook, JF; Chacko, AK , Common object request broker architecture (CORBA)-based security services for the virtual radiology environment ， Journal Of Digital Imaging, V. $13 \quad$, I. 2 , PP. $59 \quad-70 \quad, \quad 2000$

[69] Brelstaff, G; Moehrs, S; Anedda, P; Tuveri, M; Zanetti, G ， Internet Patient Records: new techniques , Journal Of Medical Internet Research, $\quad$ V. $3 \quad$ ， I. $1 \quad$ PP. $\quad$ - $\quad, \quad 2001$ 
[70] VANNIER, MW ， Computer-Applications In Radiology , Current Opinion In Radiology ， $\quad$ V. 3 ， I. 2 ， PP. 258 - 266 ， 1991 [71] Szekely, A; Talanow, R; Bagyi, P ， Smartphones, tablets and mobile applications for radiology , European Journal Of Radiology , V. 82 , I. 5 , PP. 829 - 836,2013

[72] Krupinski, EA; Jiang, YL , Anniversary paper: Evaluation of medical imaging systems , Medical Physics, V. 35 , I. 2 , PP. 645 - 659 , 2008.

[73] Ray CodyMayoJessicaLeung, Artificial intelligence and deep learning - Radiology's next frontier?, Clinical Imaging, Volume 49, May-June 2018, Pages 87-88

[74] http://radsource.us,2021 